\title{
СУБ'СКТИ МІЖНАРОДНО-ПРАВОВОГО РЕГУЛЮВАННЯ ІНТЕРНЕТ. ДІЯЛЬНІСТЬ МІЖНАРОДНИХ ДЕРЖАВНИХ ОРГАНІЗАЦІЙ В ГАЛУЗІ РЕГУЛЮВАННЯ ІНТЕРНЕТ-ВІДНОСИН
}

\author{
ШАХБАЗЯН Карина Суренівна - к.ю.н., учений секретар Центру \\ інтелектуальної власності та трансферу технологій НАН України \\ DOI:10.32782/NP.2019.4.20 \\ https://orcid.org/0000-0002-2205-374X \\ УДК 341.9
}

\begin{abstract}
Статья посвящена бормированию системъг международно-правового регулирования отношений в сети Интернет, исследованъ международные отношения, которыле сложились к этому времени в области Интернетрегулирования. Исследованъе тендениии свидетельствуют о росте роли международнъх организащий - они играют существенную роль не только в въгооре конкретнъхх направлений и содержании сотрудничества, но и в ее практической реализаиии.

Необходимость многостороннего сотрудничества является неотвемлемьм условием решения вопроса универсального характера - создания системы международно-правового регулирования отношений в сети Интернет.

Ключевъие слова: Интернет-право, международнъие правительственнвие организации, Интернет-регулирование, международно-правовое регулирование.
\end{abstract}

Постановка проблеми та їі актуальність

Система міжнародних відносин, що склалась до цього часу у галузі Інтернетрегулювання, свідчить про зростання ролі міжнародних організацій - вони відіграють істотну роль не тільки у виборі конкретних напрямків і змісті співпраці, але і в іiї практичній реалізації; також міжнародні, зокрема, урядові організації, як стабільні форми багатосторонньої співпраці, мають між собою багатоманітні зв'язки, які існують завдяки постійним контактам, i передбачають певний ступінь участі і поін- формованість щодо конкретних міжнародних заходів.

Через те, що розвиток Інтернет має загальний характер і стосується умов економічно-соціального розвитку світової спільноти i, спричинивши появу проблем, спільних для всіх країн - відтак, неможливо буде знайти їх задовільне вирішення поза межами спільної діяльності держав. Необхідність стабільної багатосторонньої співпраці є невід'ємною умовою вирішення питання універсального характеру. Однак, при цьому, для різних груп країн (розвинені країни, країни з перехідною економікою, країни, що розвиваються) характерним $є$ неспівпадіння підходів і засобів вирішення таких проблем, а також неспівпадіння у пріоритетах зовнішньої і національної політики.

Аналіз досліджень та публікацій Дослідження проблем правового регулювання відносин у телекомунікаційних мережах, зокрема відносин в Інтернет, привертає значну увагу учених різних країн. Для аналізу правового регулювання в цій галузі особливе значення мають роботи 3 теорії міжнародного права - Тункіна Г.I., Боброва Р. А., Буткевича В. Г., Аукашука І. І., Колосова Ю. М., Ушакова М. О., Черниченка С. В., Шибаєвої О. А., Поточного М., у яких розглядаються загальні проблеми науки міжнародного права, пов'язані 3 виникненням нових об'єктів міжнародно-правового регулювання. 
У зарубіжній науковій літературі питання міжнародно-правової регламентації відносин в Інтернет досліджуються досить активно. Так, під час написання роботи були враховані результати досліджень щодо міжнародно-правового регулювання відносин, пов'язаних з діяльністю в Інтернет, правників із Західної Европи та США: Я. Акденіза, Т. Белла, Х. Мовлани, М. Фрумкіна, Д. Менте, Д. Поста, Г. Перріта, ᄉ. Аесіга, ᄉ. Дамавіль.

\section{Виклад основного матеріалу}

Окремими питаннями Інтернет займається велика кількість урядових і неурядових організацій. Зараз розширяються їх функції, поглиблюється їх взаємодія між собою та державами. На даний момент відбувається розвиток системи міжнародних організацій у галузі Інтернет-регулювання, яка являтиметься важливою складовою частиною механізму управління системою відносин, пов'язаних 3 функціонуванням Інтернет. А для вирішення проблем, пов'язаних 3 порушеннями певних стандартів, необхідне регулювання на рівні міжнародних урядових організацій, які здатні застосовувати ефективні механізми провадження санкцій. «Це полегшить спільні зусилля у справі дієвого і сильного міжнародно-правового регулювання відносин, до яких залучена велика кількість різноманітних категорій учасників» [1].

Як зазначалось раніше, до компетенції урядових міжнародних організацій належить цілий спектр політичних і соціальноекономічних питань, пов'язаних з Інтернет, які стали об'єктами міжнародно-правового регулювання (МПР), зокрема, питання захисту інтелектуальної власності (компетенція ВОІВ), стандартизації (займається Міжнародний союз електрозв'язку - MCE), міжнародно-правові аспекти регулювання електронної комерції та електронного обміну даними, торгівлі (зокрема, UNCITRAL), соціальних питань (компетенція ЮHЕСКО). Нижче розглянуто питання діяльності організацій системи ООН щодо цих питань, а також ініціативи на рівні ООН - Групи 3 розгляду Інтернет-управління (World Group on Internet Governance - WGIG), яка також приділятиме основну увагу розгляду політичних і правових питань діяльності в Інтернет.

Виходячи із класифікації груп об'єктів міжнародного правового регулювання Інтернет $^{1}$, пропонується більш детальний огляд напрямів подальшої діяльності міжнародних організацій в цій галузі.

Однак, перш ніж переходити до розгляду діяльності окремих спеціалізованих міжнародних утворень в цій галузі, слід зазначити, що центральне місце в цій системі належить Організації Об'єднаних Націй.

Зараз неможливо применшити значення системи міжнародних організацій в галузі Інтернет, в центрі якої стоїть система ООН, та її спеціалізовані установи. Науково-технічна співпраця в рамках $\mathrm{OOH}$ здійснюється в умовах співіснування, співпраці держав-членів, які займають позиції, що різняться між собою, в силу чого розробка взаємо задовільних рішень вимагає довгих переговорів і співпраці при обговоренні цих проблем. У зв'язку з цим необхідно підкреслити значення цілей і принципів Статуту ООН як головного міжнародноправового засобу координації діяльності всієї системи міжнародних організацій (в розділі другому даної роботи вже зазначались загальні принципи міжнародного права (МП), закріплені в Статуті ООН, які регулюють відносини, пов'язані з ІКТ).

Зокрема, це стосується міжнародноправового регулювання групи відносин, що стосуються технічного функціонування Інтернет. На відміну від міжнародного електрозв'язку, який розвивається впорядковано, акти, що регулюють технічні умови розвитку Інтернет, державами прийняті не були: «В цей час розвиток глобальної комп'ютерної мережі забезпечується колективними зусиллями іiі користувачів, об’єднаних в Суспільство Інтернет» [2, с.3].

\footnotetext{
${ }^{1}$ Можливо виділити два типи об'єктів регулювання, пов'язаних $з$ функціонуванням Інтернет: 1)Технічний інжиніринг, який дозволяе співдіяти різним компонентам Інтернет, а також технічна координація ключових протоколів, адрес і імен, від яких залежить технічне функціонування Інтернет. 2) Питання публічної політики (зазначені нижче), які мають розглядатись на рівні урядів, із широким залученням громадського суспільства і бізнес-структур.
} 


\section{Міжнародне право}

Кожен з їі користувачів вправі внести свої пропозиції щодо технічного вдосконалення мережі, сформулювавши проект нового стандарту мережі, який потім приймається Органом 3 конструювання Інтернет. Однак, для рішення технічних проблем Інтернет зусиль окремих користувачів, які координуються спільнотою Інтернет, недостатньо.

Саме тому представляється актуальною необхідність міжнародно-правового регу^ювання розвитку мережі на універсальному рівні шляхом укладання міжнародних договорів (або утворення нових міжнародних організацій - як пропонує В. Талімончик), чи, вірогідніше, на нашу думку, надання додаткових функцій вже існуючим міждержавним організаціям.

Міжнародний союз електрозв'язку (МСE) є однією 3 головних міжнародних організацій у сфері телекомунікацій. Основні документи Союзу - це Статут і Конвенція міжнародного союзу електрозв'язку, ухвалені у 1992 р. і ратифіковані Україною 11 липня, 1994 року. МСЕ належить істотна роль в міжнародно-правовому регулюванні електрозв' язку. Він здійснює функції по встановленню єдиних технічних нормативів для дротового зв’язку і розподілення частотного спектру. Згідно п.1 ст. 1 Статуту МСЕ від 22 грудня 1992р., до цілей Союзу відносяться сприяння розвитку технічних засобів і їх найбільш ефективна експлуатація. По відношенню до Інтернет вказане положення виявилось декларативним. Ані в Статуті МСE, ані в Конвенції МСE від 22 грудня 1992 року положень щодо заходів по координації розвитку і використання комп'ютерних мереж не міститься. За відсутності необхідних правових положень в рамках MCE на було прийнято адекватних заходів, що забезпечили б функціонування Інтернет на базі існуючих мереж зв'язку.

Безперечно, що із збільшенням кількості користувачів Інтернет, складності в отриманні інформації будуть зростати. Для забезпечення впорядкованого розвитку мережі у взаємодії з існуючими засобами зв'язку, держави будуть змушені здійснювати регулювання комп'ютерного зв'язку, істотним чином розширюючи функції МСЕ. Відповідно, розділ 7 Конвенції MCE і Глава 4 Статуту МСE, що регламентують сектор розвитку електрозв'язку, вимагатимуть істотних доповнень. В рамках МСЕ повинна бути розроблена якісно нова концепція розвитку електрозв'язку, що враховуватиме закономірність взаємодії електрозв'язку і комп'ютерних мереж.

Розвиток Інтернет обумовлюе необхідність конкретизації функцій не тільки MCE, але й інших міждержавних організацій.

Як зазначалось раніше, до цього часу діяльність міжнародних організацій тільки опосередковано сприяла розвитку мережі. Певні заходи, пов'язані із забезпеченням розвитку Інтернет, міждержавними організаціями не здійснювались. Більше того, створення в рамках Міжнародної організації по стандартизації у 80-х рр. стандартів OSI («Взаємодія відкритих систем») [3] призвело до того, що окремі частини глобальної комп'ютерної мережі стали функціонувати за різними технічними стандартами. Європейські мережі використовують стандарти OSI, а американські і ряд інших мереж, що входять до системи Інтернет, використовують протоколи ТСР $\backslash \mathrm{IP}$.

Сприяння розвитку мережі з боку міжнародних організацій в більшості обмежується заходами загального характеру, які спрямовані на розвиток міжнародного інформаційного обміну в цілому, а не конкретно мережі Інтернет. Так, наприклад, по відношенню до системи Інтернет застосовується концепція нового інформаційного порядку, сформована в резолюціях №4\21 21 сесії Генеральної Конференції ЮНЕСКО і №33\115 від 18 грудня 1978p. Генеральної Асамблеї ООН. Одночасно iз затвердженням концепції нового міжнародного інформаційного порядку Генеральна Конференція ЮНЕСКО заснувала Міжнародну програму розвитку комунікації, для здійснення якої була утворена Міжурядова Рада в складі 35 представників держав. Разом з тим варто враховувати, що Міжурядова Рада приймає політичні і економічні заходи, що забезпечують збалансований інформаційний обмін між державами. Вирішення проблем технічного 
розвитку глобальних електронних комунікацій у його компетенцію не входить.

Незалежно від можливих шляхів вирішення проблеми, регулювання розвитку Інтернет саме на рівні міжурядових організацій представляється досить обгрунтованим: адже, не дивлячись на те, що Інтернет являється технічною системою, всі учасники інформаційного обміну в мережі роз'єднані в організаційно-правовому аспекті. Інтернет розвивається як децентралізована система.

У порівнянні з вирішенням технічних питань функціонування Інтернет, участь міжнародних урядових організацій стосовно регулювання соціально-політичних і економічних питань Інтернет, є набагато більш активною.

Стрімке поширення Інтернет в дев'яностих роках не відбулось би без відповідної внутрішньої політики і торговельних угод, які лібералізували впровадження інформаційних послуг 3 використанням телекомунікаційних засобів. Ці угоди передували появі Всесвітньої торгової організації (ВТО). Згодом ї було надано законного статусу у ВТО під назвою Угода про базові телекомункації (WTO’s Basic Telecommunication Services agreements). Крім того, ВТО разом із ВОІВ поширюе Угоду 3 торговельних аспектів прав інтелектуальної власності - TRIPS (Traderelated aspects of intellectual property rights), яка визначає порушення авторських прав як бар'єр для здійснення вільної торгівлі і вимагає від членів ВТО притримуватись мінімальних стандартів захисту і впровадження прав. Хоч i не безпосередньо пов'язане 3 інтелектуальною власністю в Інтернет, застосування стандартів TRIPS також може застосовуватись і до правопорушень в сфері Інтернет ${ }^{2}$.

\footnotetext{
2 Положення TRIPS сприяє утворенню нового, більш високого у порівнянні з існуючим, механізму охорони прав на інтелектуальну власність, зокрема Угода зобов'язує: застосовувати норми із останнього варіанту Бернської конвенції про охорону літературних і художніх творів, тим самим розширює обсяг впливу охорони, наданої по Бернській конвенції.Положення TRIPS також зобов'язує уряди всіх країн впровадити дієві заходи боротьби з піратством (незаконним виробництвом і поширенням)
}

В області електронної комерції провідна роль у роботі з правової уніфікації належить Комісії ООН 3 міжнародного торгового права (The UN Commission on International Trade Law (UNCITRAL), Міжнародній торгівельній палаті та Европейській економічній комісії, до основних документів яких відносяться:

- Типовий закон UNCITRAL «Про електронну комерцію» 1996 року; підготовка Типового закону здійснювалась за участю представників усіх держав - членів UNCITRAL, а також таких організацій, як ЮНИДО, Гаазької конференції з міжнародного приватного права, Федерації латиноамериканських банків (FELABAN), Банківської федерації Европейського Співтовариства, Міжнародної торговельної палати і ряду інших, що забезпечило широке представництво зацікавлених сторін та всебічне вивчення питань.

- Стандарт UN/EDIFACT і Типова угода про обмін даними при міжнародному комерційному використанні електронного обміну даними (Рекомендація № 26, прийнята Робочою групою по спрощенню міжнародних торгових процедур Европейської економічної комісії ООН, 1995р., Женева);

- Сдині правила поведінки при здійсненні обміну комерційною інформацією 3 використанням засобів зв'язку, Міжнародна торговельна палата, 1987 р.

Також, в рамках роботи UNCITRAL було розроблено проект Конвенції з використання електронних повідомлень в міжнародних контрактах [3], яка була прийнята у 2005 р. ООН. Ця Конвенція спрямована на врегулювання правил обміну повідомленнями стосовно міжнародних контрактів. В ній визначено шляхи встановлення розташування сторін контракту в е-середовищі, час та місце відправлення і отримання електронних повідомлень, використання автоматичних систем створення контрактів, встановлено функціональні еквіваленти між електронними повідомленнями та паперовими документами, а також між електронними методами аутентифікації та звичайним підписом. 


\section{Міжнародне право}

Оподаткування електронної комерції також стало предметом розгляду міжнародної спільноти. Організація з економічного розвитку підготувала проект Документу щодо оподаткування фінансових операцій в Інтернет [5]. Розробка цього проекту відбувалась у тісній співпраці з Европейським Союзом і Всесвітньою Митною Opганізацією (World Customs Organization). 10 жовтня 1998 року OECD опублікувала перелік 28 «Варіантів впровадження» («Implementation Options») - пропозицій методів із оподаткування учасників електронної комерції.

Всесвітня організації інтелектуальної власності (ВОІВ) також відіграє істотну роль у сфері міжнародно-правового регулювання використання та охорони об'єктів інтелектуальної власності в Інтернет. ЇЇ головна мета - забезпечення міжнародно-правового регулювання, захисту інтелектуальної власності, проведення аналізу світового досвіду вирішення проблем, пов'язаних 3 міжнародним характером діяльності в мережі.

В рамках діяльності цієї організації iз захисту авторських прав слід відмітити підготовку так званих «Договорів в сфері Інтернет», які вдосконалюють механізм захисту авторських та суміжних прав, що існував до створення Інтернет, пристосовуючи його тим самим до середовища цифрових технологій.

Договір з авторського права - «найкращий інструментарій для вирішення технологічних проблем в кіберпросторі» - відмітив Генеральний директор ВОIB Каміль Ідріс, - «ці договори представляють собою нову ступінь в модернізації міжнародного законодавства по авторському праву і суміжним правам в цифровій ері.... і мають ключове значення для подальшого розвитку Інтернет, електронної торгівлі і, відповідно, для розвитку індустрії розваг та інформації. Вони допоможуть забезпечити стан, при якому творчі діячі зможуть отримати необхідний захист від піратства в Інтернет» [6].

Однією з нагальних проблем охорони прав інтелектуальної власності в Інтернет є проблема доменних імен. ВОІВ розгля- дає це питання, починаючи з 1996 року. Розвиток Інтернет породив нову конфліктну ситуацію, пов'язану з використанням вже зареєстрованих товарних знаків в якості адресних найменувань інформаційних вузлів і сторінок у мережі (доменів) кіберсквотінг («суbersquatting»).

У 1998-1999 роках відбувся перший етап розгляду проблем, пов'язаних 3 доменними іменами (First WIPO Internet DN Process), який закінчився прийняттям Кінцевого звіту 30 квітня, 1999 року і підготовкою Единої політики розгляду суперечок з приводу доменних імен (Uniform Domain Name Dispute Resolution Policy), яка була прийнята ICANN у грудні 1999. У 2000-2002 роках відбувся другий етап розгляду проблем, пов'язаних 3 доменами (Second WIPO Internet DN Process), який визначив інші проблемні питання в цій галузі, ніж ті, що пов'язані лише 3 торговельними марками.

ВОIВ в 1999 р. приймається план дій щодо регулювання інформації у цифровій формі (WIPO Digital Agenda), в якому закріплено цілі і напрямки діяльності ВОІВ у галузі розробки рішень проблем, що виникають у зв'язку з впливом нових технологій на права інтелектуальної власності - зокрема, захист авторського права, розвиток е-комерції, права організацій мовлення, принципи відповідальності сервіспровайдерів.

При ВОІВ створено Арбітражний центр із вирішення конфліктів, пов'язаних 3 незаконним використанням доменних імен у зонах .com, .net, чи .org, а також у доменних зонах деяких країн, які погодились 3 відповідними арбітражними функціями BOIB. Застереження про вирішення подібної суперечки Арбітражним центром включено у Типовий договір щодо реєстрації доменного імені в цих зонах. До цього часу Центром розглянуто більше 6000 справ. Варто врахувати, що Центр приймає рішення тільки про неправомірність використання того чи іншого ідентифікатора в доменному імені і не розглядає жодних майнових вимог, що випливають 3 цих конфліктів. Центр визначає правоздатність сторони на використання доменного імені, і якщо виявляється, що зареє- 
строване доменне ім'я вводить в оману або неправомірно використовується, воно має бути передано законному власнику. Під «неправомірним використанням» розуміється, що доменне ім'я зареєстроване з метою продажу, здачі в оренду чи іншого відчуження третім особам, що мають права на даний ідентифікатор. Створення подібного Центру є першим кроком до уніфікації принципів вирішення спорів, пов'язаних 3 доменними іменами.

ООН визначив саморегулювання (а також, співрегулювання), як один із важелів розвитку електронної комерції в світі: в 2001 році Центром ООН із спрощення торгівельних процедур і електронного бізнесу (Centre for Trade Facilitation and Electronic Business (UN/CEFACT) було підготовлено наступний документ: «Рекомендація №32 - щодо інструментів саморегулювання в галузі електронної торгівлі (кодексах поведінки)». Тема: «Спрощення торговельних процедур» [7, с.45-46]. Детальніше - у наступному підрозділі даного розділу.

Слід відмітити, що правові засади розвитку Інтернет повинні формулюватись на універсальному рівні не звичаєво-правовим шляхом, який для технічної системи є занадто довгим, а засобами розширення компетенції міжнародних організацій, зокрема, МСЕ. При цьому, доцільно внести зміни до статутів вказаних міжнародних організацій 3 метою закріплення конкретних повноважень із сприяння технічному розвитку мережі.

Подальші перспективи Інтернет-регулювання на рівні міжнародних державних організацій.

На універсальному рівні питання сутності Інтернет, як сфери правового регулювання, почали привертати пильну увагу. Як зазначалось раніше, в 2003 і 2006 роках відбувся ряд заходів за участю організацій системи ООН, присвячених саме розгляду перспектив розвитку Інтернет-регулювання: МСЕ було проведено Всесвітній саміт інформаційного суспільства (the World Summit on the Information Society (WSIS) ${ }^{3}$,

\footnotetext{
3 Проведення цього заходу закріплено в наступному документі ОOH: The UN General Assembly Resolution 56/183 (21.12.01) .
}

метою якого було сприяння поширенню Інтернет, а результатом якого стало прийняття Декларації принципів і Плану дій (Declaration of Principals and Plan of Action), а також рішення, згідно якого Генеральний Секретар ООН сформував Робочу групу з Інтернет Регулювання (Working group on Internet governance - WGIG).

Під час підготовки до першого раунду цього Саміту (грудень, 2003р.) вже чітко визначились позиції основних суб'єктів правового регулювання стосовно того, який шлях Інтернет-регулювання обрати. Уряди країн, що розвиваються, намагаються поставити Інтернет під контроль ООН або установ системи ООН - так визначили позицію опонентів представники США i EC, і виступили проти таких заходів, зазначивши, що продовжуватимуть боротьбу за те, щоб керування Інтернетом лишалося збалансованим між всіма учасниками та залишилося у приватного сектора.

Багато країн, що розвиваються, вважають, що міжнародним урядовим організаціям повинна належати важлива роль у керуванні Інтернет i визначенні його політики. Згідно зазначеної Декларації, країни, що розвиваються, і країни з перехідною економікою вважають за необхідне передати ці функції структурі ООН - MCE. А на думку США, Европейського союзу, Японії і деяких інших країн, державне втручання може загальмувати розвиток цього динамічного засобу обміну інформацією. Одні представники міжнародної спільноти вважають, що Інтернет занадто важливий, щоб залишати його керування в руках однієї держави. Інші представники Інтернет-спільноти вважають, що зростання кіберзлочинності і проблеми захисту інтелектуальної власності вимагають втручання міжнародних урядових організацій. Зокрема, Китай, Росія, Індія, Бразилія, Саудівська Аравія, Південна Африка і багато інших держав вважають за доцільне, щоб ООН належала більш важлива роль.

На Саміті WSIS 2005 р. окрему увагу привертали такі питання, як боротьба 3 поширенням комп'ютерних вірусів і спаму, підтримка свободи слова в Інтернет, запобігання використанню Інтернет в пра- 


\section{Міжнародне право}

вопорушних цілях (наприклад, крадіжка ідентифікаційної інформації). Однак, головною метою Саміту є розробка єдиної позиції щодо інформаційного суспільства, використання нових технологій для перемоги над бідністю і пошуку шляхів перетворення Інтернет у засіб обміну інформацією, що є доступним для всіх.

Координація Саміту здійснюеться Організаційним Комітетом на вищому рівні (High-Level Summit Organizing Committee) під особистим патронажем Генерального секретаря ООН, а ведуча роль в проведенні Саміту належить МСE. В роботі Саміту приймають участь всі відповідні організації ООН, інші міжнародні міжурядові організації, міжнародні неурядові організації, представники приватного сектору, громадського суспільства і медіа - для залучення до процесу всіх зацікавлених сторін.

Метою першого раунду було розробити і прискорити встановлення і розбудову Інформаційного Суспільства для всіх, а результатом цього стало прийняття Декларації принципів і Плану Дій. Зараз робочі групи працюють над визначенням механізмів Інтернет-управління і фінансування. Безпосередньо, до завдань Робочої групи 3 Інтернет регулювання (Working Group on Internet Governance - WGIG) відносяться розробка визначення термінів Iнтернет-регулювання, ідентифікація питань публічної політики, що стосуються Інтернет-регулювання, розробка спільного розуміння повноважень і зобов'язань урядів, міжнародних організацій і інших зацікавлених учасників міжнародних відносин у галузі Інтернет, так само, як і приватного сектору і громадського суспільства в розвинених країнах, і країнах, що розвиваються. Визначення кола питань, що потребують подальшого розгляду і вивчення, обумовлюється тим, що при підготовці до проведення Саміту було виявлено, що не існує єдиного розуміння ключових питань, зокрема, сутності і механізмів самого Інтернет-регулювання.

Наприклад, позиція СIIA полягає в тому, що Інтернет-регулювання має здійснюватись при багатосторонньому підході і обов'язково регулюватись приватним сек- тором (тобто, залишити управління мережею в повноваженні ICANN). Така позиція не отримує підтримки в країнах, що розвиваються, адже, вони зазначають, що є недостатньо залученими до сучасної системи регулювання, в той час як Інтернет довгий час лишався монополією СШІА, і його потужність зростає по всьому світу, ICANN не може лишатись контролюючою установою.

Пропозиція країн, що розвиваються, щодо Інтернет-регулювання є наступною: адміністративні і технічні питання, такі як розподілення (розміщення) ресурсів i управління іменами повинні знаходитись в компетенції міжнародної організації, такої як, MCE, що належить до системи агенцій $\mathrm{OOH}$.

Позицію США щодо того, що управління Інтернетом має лишатись в ICANN, також підтримують EC, Японія і Австралія. Представники цих країн впевнені, що адміністрування Інтернет на рівні МСE спричинить встановлення бюрократичного контролю над ресурсами мережі.

На нашу думку, такі побоювання не є досить виправданими. По-перше, управління Інтернет ресурсами, яке здійснюється зараз ICANN, також має свої недоліки непрозорість і відсутність представництва в процесі функціонування i прийняття рішень вже не відповідають характеру Інтернет, який перетворився на глобальний медіа-ресурс. При поширенні Інтернет, все більший розмах отримали такі проблеми, як дитяча порнографія і спам, порушення прав інтелектуальної власності. Певні питання стосовно контенту Інтернет-ресурсів повинні стати об'єктами регулювання саме міждержавних організацій. При цьому, питання зміни суб'єкту адміністрування Iнтернет не буде вирішуватись до проведення наступного раунду WSIS, а визначення термінів, що стосуються Інтернет-регулювання, і того, який орган цим займається, має бути здійснено найближчим часом. Ці питання намагались вирішити під час першого раунду переговорів, але значна розбіжність думок 3 цього питання запобігла прийти до одностайного визначення, а відтак, і до Плану Дій конкретних норм 3 цього приводу включено не було - авто- 
ри обмежились лише загальним формулюванням декларативних принципів регулювання Інтернет «згідно загальновизнаних норм міжнародного співтовариства і відкритості інформаційного суспільства».

Результатом Саміту став документ, який підтвердив основні положення Декларації принципів, прийнятої в Женеві в 2003р. Робоча група з управління Інтернет (Working Group on Internet Governance - WGIG) прийняла документ, в якому зазначені основні напрямки розвитку Інтернет-управління на міжнародному рівні. Зокрема, в документі міститься ряд важливих положень щодо визначення самого управління мережею, суб'єктів такого управління та шляхів його вдосконалення. Управління Інтернет визнається важливим елементом Інформаційного суспільства, яке впливає на значну кількість питань державної політики. Також було визначено зобов'язання урядів, міжурядових і неурядових міжнародних організацій, а також приватного сектору і громадської спільноти країн. Інтернетуправління було визначено як «розробка і застосування урядами, приватним сектором і громадським суспільством спільних принципів, норм, правил, процедур прийняття рішень та програм, які формують еволюцію та використання Інтернет» [8]. Стосовно спільного управління Інтернет, то визначалось, що кожен учасник має відповідати за регулювання окремих аспектів Інтернет. Так, наприклад, закріплювалось, що державна політика є виключно прерогативою урядів, приватний сектор впливає на розвиток Інтернет в технічній та економічній сферах, міжурядові організації повинні продовжувати процес координації вирішення питань державної політики щодо Інтернет, а міжнародні неурядові організації мають продовжувати розробку технічних стандартів Інтернет.

Позитивним в цьому документі 6 намагання покращити координацію діяльності міжнародних урядових і неурядових міжнародних організацій стосовно Інтернет-регулювання. Також в документі зазначено необхідність розробки відповідної регіональній політики для гарантування забезпечення національних інтересів i прав країн певного регіону при управлінні їх власними Інтернет - ресурсами. Інший позитивний момент - це окремо визначена необхідність усебічної підтримки кібербезпеки та боротьби із кіберзлочинністю, боротьба зі спамом.

Зазначено, що робота з цього приводу має продовжуватись і було запропоновано провести Форум з Інтернет - регулювання під егідою генерального секретаря ООН, який би визначив наступні питання: визначення ключових питань державної політики у цій галузі, прискорення взаємодії між суб'єктами такого регулювання, проведення відповідної наукової експертизи, надання рекомендацій.

Для виконання вищенаведених завдань було запропоновано План дій щодо Інтернет - регулювання. Характерною ознакою його стало визначення окремих напрямків подальшої роботи учасників Саміту з визначенням відповідальних міжурядових організацій. Зокрема, до них було включено визначення ролі урядових структур та інших учасників сприяння розвитку ІКТ на міжнародному рівні (відповідальні організації - ECOSOC/UN Regional Commissions/ITU), інформаційна i комунікаційна інфраструктура - (ITU), доступ до інформації і знань (ITU/UNESCO), безпечне користування IKT (ITU), електронне урядування та (UNDP/ITU), електронна комерція (WTO/UNCTAD/ITU/ UPU), е-освіта (UNESCO/ITU/UNIDO), е-медицина (WHO/ITU), міжнародна і peгіональна співпраця на рівні регіональних комісій ОOH та інших організацій (UNDP/ ITU/UNESCO/ECOSOC).

Висновки. Сутність проблем, пов'язаних 3 Інтернет-регулюванням, полягає в тому, що їх вирішення не може бути знайдене поза рамками глобальної співпраці, адже «виникнення потреби вирішення глобальних проблем не просто спричиняє розширення функцій і компетенції міжнародних організацій, а й означає якісно новий етап в розвитку останніх» [9].

При здійсненні правового регулювання Інтернет, слід враховувати головну ознаку цієї інформаційної мережі, а саме, iii «міжнародний» характер, який повинен 


\section{Міжнародне право}

знайти відповідне відображення як в національному праві, так i в міжнародному праві. Основним завданням міжнародноправового регулювання в даній сфері є забезпечення взаємодії держав і координація їхніх зусиль в організації всесвітнього інформаційного обміну ${ }^{4}$.Формою такого співробітництва, перш за все, має стати робота в міжнародних урядових і неурядових організаціях, а результатом - розробка та прийняття міжнародних угод, модельних актів по всьому спектру правовідносин, що виникають при використанні нових IКТ, і зокрема, Інтернет.

Механізм прийняття рішень міжнародними організаціями має істотні позитивні сторони, що отримують велике значення в цей період становлення системи міжнародного регулювання Інтернет. Міжнародним організаціям належить роль центрів 3 обговорення, вивчення, підготовки, узгодження і прийняття рішень 3 відповідних питань. Ці рішення оформлюються шляхом рекомендацій чи угод між державами. Зростає роль організацій як центрів по врегулюванню співпраці в даній області. Організації - не тільки засоби досягнення рішення, але й активні учасники регулювання. Вони приймають рішення, які отримують юридично - обов'язкову силу, а також самі є сторонами в міжнародних договорах і т.д. Завдяки міжнародним організаціям вирішення міжнародних про-

\footnotetext{
${ }^{4}$ До речі, така позиція знайшла своє відображення і в українському законодавстві - в Указі Президента «Про заходи щодо розвитку національної складової глобальної інформаційної мережі Інтернет та забезпечення широкого доступу до цієї мережі в Україні» від 31 липня 2000 року N 928/2000 зазначено, що «Міністерству закордонних справ України, Мiністерству економіки України із залученням інших центральних органів виконавчої влади: опрацювати питання щодо вступу України до відповідних міжнародних організацій, що займаються питаннями розвитку телекомунікаційних систем, захисту прав на інформацію, протидії поширенню інформації, яка завдає шкоду людині і громадянину, суспільству і державі ». (Указ Президента України «Про заходи щодо розвитку національної складової глобальної інформаційної мережі Інтернет та забезпечення широкого доступу до цієї мережі в Україні» від 31.07.2000 № 928/2000 // Офіційний вісник України - 2000. - № 31. - С.11)
}

блем, пов'язаних 3 Інтернет, являється предметом широкого політичного розгляду та створює сприятливі умови для всебічного залучення світової спільноти.

\section{Мiтература}

1. Martin Lisa L. Coercive Cooperation: Explaining Multilateral Economic Sanctions / L. Martin. - Princeton: Princeton University Press, 1992 - 299 p.

2. Талимончик В.П. Международноправовое регулирование отношений информационного обмена в Інтернет : автореф. на соискание наук. степени канд. юр. наук : 12.00.11 «международное право» / В.П. Талимончик. - СПб., 1999. - 160 с.

3. Храмцев П.Б. Аабиринт Интернет / П.Б. Храмцев. - М. : «Информационные технологии», 1996. - 360 с.

4. UN Convention on the Use of Electronic Communications in International Contracts - [Електронний ресурс] - Режим доступу до документу: http://www.uncitral.org/pdf/english/texts/electcom/2005Convention.pdf

5. «Statement of Policy, Management of Internet Names and Addresses», National Telecommunications and Information Agency, 1998, [Електронний ресурс] - Режим доступу до документу: http://www.ntia.doc. gov/ntiahome/domainname/6 5 98dns.htm.

6. Днепровский А.Г. Правовые проблемы нового международного информационного порядка / А. Днепровский. - М: Наука., 1989. - 142с.

7. Recommendation of the EU Commission of 18 May 2005 on collective cross-border management of copyright and related rights for legitimate online music services 2005/738/EC // Official Journal of the European Union, L 276 - Vol. 48. - 2005. - P. 45-46.

8. Tunis Agenda for the Information Society. Internet Governance WSIS - [Електронний ресурс] - Режим доступу до документу: www.wsis.org.

9. Актуальные проблемы деятельности международных организаций: теория и практика / научн. ред. Г.И. Морозов. - М.: Междунар. отношения, 1982. - с. 340. 


\section{АНОТАЦІЯ}

Система міжнародних відносин, що склалась до изього часу у галузі Інтернет-регулювання, свідчить про зростання ролі міжнародних організацій - вони відіграють істотну роль не тільки у виборі конкретних напрямків $і$ змісті співпраці, але $і$ в ї̈ практичній реалізаиіï.

Через те, що розвиток Інтернет має загальний характер $і$ стосується умов економічно-соціального розвитку світової спільноти $i$, спричинивши появу проблем, спільних для всіх країн - відтак, неможливо буде знаити їх задовільне вирішення поза межами спільної діяльності держав. Необхідність стабільної багатостороннъої співпрачі $\epsilon$ невід'ємною умовою вирішення питання універсального характеру - створення системи міжнародно-правового регулювання відносин в мережі Інтернет.

Subjects of interntional legal

regulation of the Internet. Activitites of the international state organizations in the field of Internet- relationas regulation.

The current system of international relations in the field of Internet regulation testifies the growing role of international organizations - they play an important role in the choice of specific directions and content of cooperation, as well as in its practical implementation; also international organizations, in particular governmental organizations, as stable forms of multilateral cooperation, have a multifaceted link between each other through ongoing contacts and with a certain degree of involvement and awareness of specific international activities. Due to the fact that the development of the Internet is of a general nature and concerns the conditions of economic and social development of the world community and, causing problems common to all countries, it will not be possible to find a satisfactory solution beyond the joint activity of states. The need for stable multilateral cooperation is an indispensable condition for resolving this issue of universal nature. However, different groups of countries (developed countries, countries with transition economies, developing countries) are characterized by a mismatch of approaches and means of solving such problems, as well as a mismatch in the priorities of foreign and national policy of cyberlaw.

Keywords: Legal regulation of Internet, International Governmental Organizations, international and legal regulation. 